\author{
Vol. 16, No. 12, December, 1952 \\ 日本金屬學會誌 \\ 第 16 洛 第 12 號

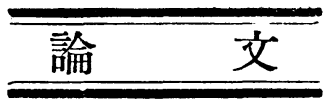
セレンおよびその合金の研究 (第7 報) セレンの經年變化についで

佐藤知雄 ${ }^{* *}$ 金子秀夫增本 剛**

Tomo-o.Satô, Hideo Kaneko and Katashi Masumoto: Studies on Selenium and Its Alloys (VII). On the Aging of the Electrical Resistance of Selenium.

The main causes of the aging of selenium rectifier are the change of electrical resistance of blocking layer and that of selenium layer. To make clear the phenomenon based on the later cause and to supply some fundamental data for the prevention of aging of the rectifier, the present authors have measured the change of the electrical resistance of selenium layer when it is heated under various conditions. The results obtained are as follows: the electrical resistance of selenium containing chlorine or bromine increases rapidly for the first few days of the aging period and thereafter shows constant resistance, while that of selenium containing iodine increases slowly during all period. Under the condition of high temperature and humidity, the increase of resistance is comparatively large. Considering the character of the rectifying plate from the stand point of electrical conductivity, therefore, selenium containing chlorine gives the best result, but from the stand point of aging, it is considered that selenium containing iodine is the most stable.

(Received August 21, 1952)

\section{I. 酳}

セレン整流板の經年變化は整流器性能に重要な影響を括 よぼすものであるが，この經年變化の原因は單一のもので はなく，種々の因子が影響するものと考えられる，その主 要なものは堰層の變化とセレン㝠の抵抗の變化との二つで

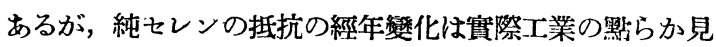
ると注とんど認められない，しかし添加劑を含むセレンの 抵抗の經年變化は著しい，そこで本研究においては，この 添加㐿を含むセレン㸴自體の抵抗の時間的變化を種々なる 條件の下に拈いて測定し，經年劣化防止の基礎資料となし たものである.

\section{II. 試料および裝置}

試料は $\mathrm{Se}_{2} \mathrm{Cl}$. $\mathrm{Se}_{2} \mathrm{Br}_{2}$ および $\mathrm{Se}_{2} \mathrm{I}_{2}$ を母合金として, $\mathrm{Cl}, \mathrm{Br}$ 抢よびI をそれぞれ $1 \%$ 抢よび $0.05 \%$ 含ませた Se で, 直巠約 $0.5 \mathrm{~cm}$, 長さ約 $3 \mathrm{~cm}$ の圆杜狀に鑄造し 110〜120 において 1 時間熱處理し結晶化させた後, さら に190〜200 に执いて1 時間熱處理して電導度を增加させ

** 東北大學工學部金屬工學科

* 1950 年 4 月本會東京大會に發表

た試料 6 種類について，電氣抵抗の經年變化を約 60 日間 にわたつて測定した・溫度拉び濕度の影響をしらべるた

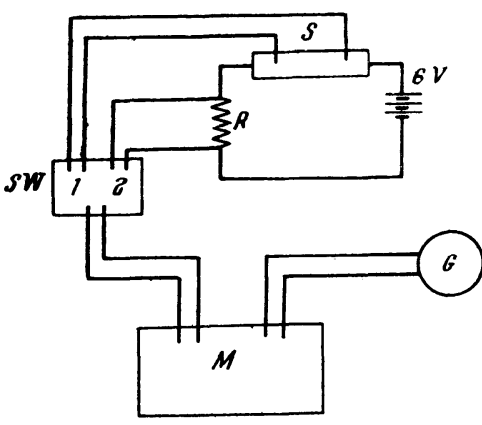

Fig. 1 The Schematic Diagram of Measuring Circuit of Electrical Resistance.
め, 試料の溫度

を常溫括よび $100^{\circ}$ に，また濕 度を $0 \%$, 常濕 特よび $100 \%$ に變化させた。 測定裝置は Fig.1に示す 如くであつて, $\mathrm{S}$ は試料， $\mathrm{R}$ は 標準抵抗箱, $\mathrm{SW}$ は多重切換 えスイッチ, M はポテンシォメーター, G は銳感電流計 である. まづ 2 の測定害筀より試料に流れる電流值を求 め，これと 1 の测定電悘とから試料の抵抗を求めた.

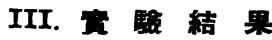

60 日間電氣抵抗を測定した結果を, 縱軸に比抵抗，橫 軸に日數を取つて六せば Fig.2〜4 の如くなる. 以下各 
くの試料について說明を加えよら。

\section{Cl1\%を含む試料}

Fig. 2 (A) に示与如く各試料とも保持持間と〉もに比

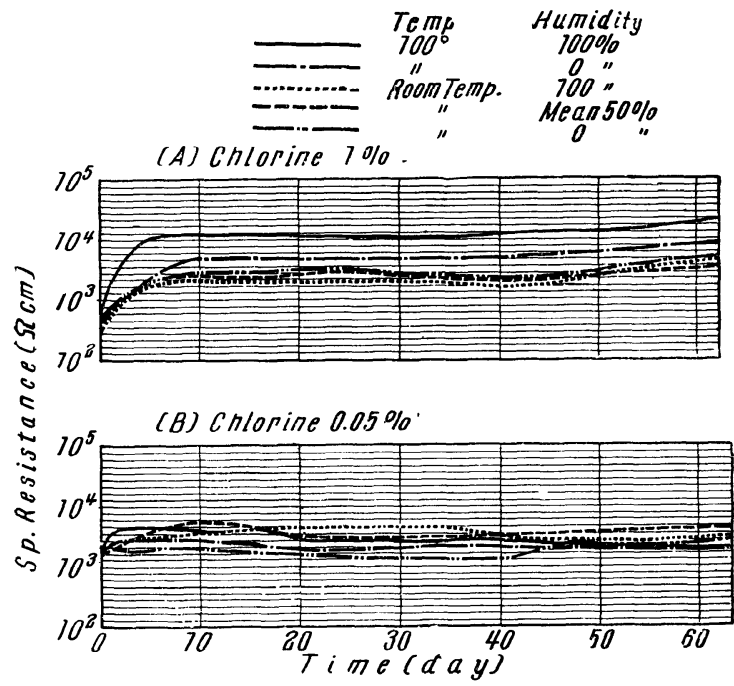

Fig. 2 The Aging of the Electrical Resistance of Selenium Containing Chlorine.

抵抗は增加与るが，約 7 日で大體一定値に近づく，各曲線 を比較して見ると，溫度 $100^{\circ}$ ，濕䯧 $100 \%$ の條件下の試 料は溫度 $100^{\circ}$, 濕度 $0 \%$ のものよりも抵抗㒄加の程度が 大である. 常温に保持した場合は $100^{\circ}$ の場合上りも抵抗 哂加が小であるが，濕度を０％，常濕怙よび $100 \%$ に變 えても大なる差珙は認められない。

\section{2. $\mathrm{Cl} 0.05 \%$ を含む試料}

Fig. 2 (B) に示す如く約 3 日で比抵抗は一定となる. Cl の含有量が少ないため各曲腺ともほ汇同一の傾问を示 している.

$\mathrm{Cl}$ を $1 \%$ 含む場合と $0.05 \%$ 含む場合とを比較して見 ると，最初つ抵抗值は $0.05 \%$ の方が大である.一定値に 到達した後つ抵抗値は何れの場合も活心同一であるから， $1 \%$ の方が $0.05 \%$ \%のより抵抗增加率が著しいことに なる。

\section{3. $\mathrm{Br} 1 \%$ を含む試料}

Fig. 3 (A) に示寸如く約 5 日で比抵抗は大體一定に なり，その後は徐々に㴚加する. 各曲線を比較して見ると $\mathrm{Cl} 1 \%$ を含を場合と同樣，溫度 $100 \%$ ，濕度 $100 \%$ の場 合が抵抗哂加が最も大で，溫度 $100^{\circ}$ ，濕菨 $0 \%$ の場合が これに资いで扔る. 常溫の場合は濕度の如问にか人わらず ほ心゙同一の傾向を示している.

\section{4. $\mathrm{Br} 0.05 \%$ を含む試料}

Fig.3 B) に示与如く $\mathrm{Br} 1 \%$ の場合と同様，比抵抗は 約 5 日で大體一定になり，その後は徐々に增加する. 各曲 線とも汪心゙同一の抵抗堆加過程を經ている．Br の場合は $\mathrm{Cl}$ の場合と多少翼なり，約 5 日で比抵抗は大體一定にな るが，その後も徐々に增加している。

5. I1\%を含む試料
Fig.4(A)に示扣くで，Iを含む場合は $\mathrm{Cl}$ および $\mathrm{Br}$ の場合と買なり，急激な 抵抗增加性全然証められず， 最初から全期間にわたり徐々に比抵抗は㒄加する. 各曲線

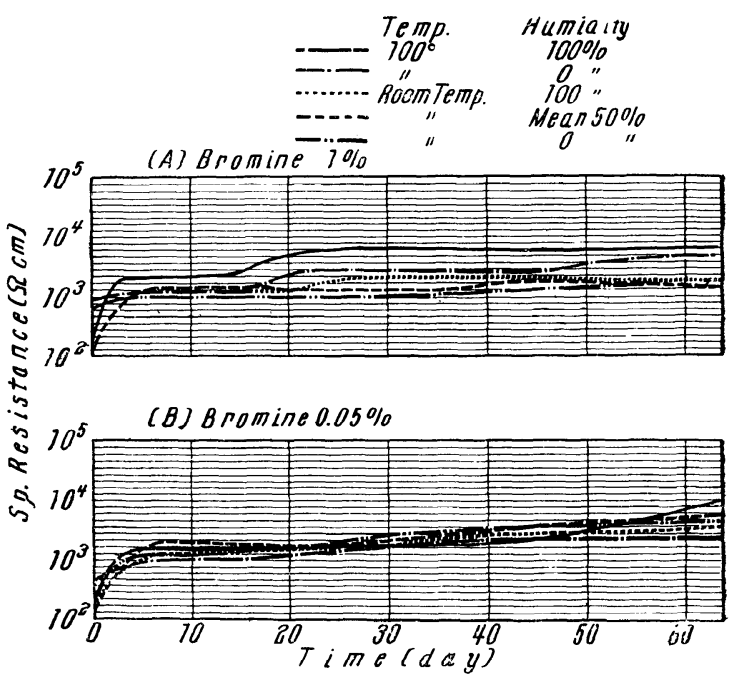

Fig. 3 The Aging of the Electrical Resistance of Selenium Containing Bromine.

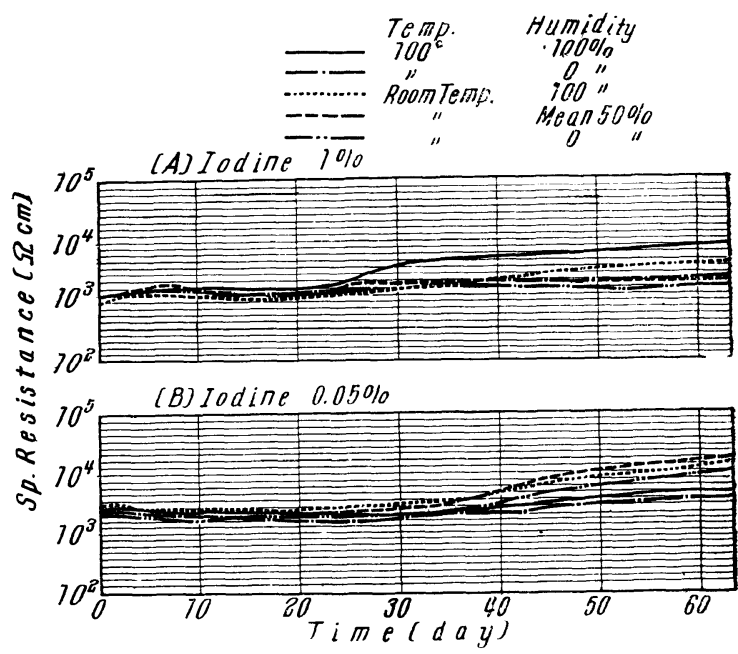

Fig. 4 The Aging of the Electrical Resistance of Selenium Containg Iodine.

を比較して見ると，約 2,3 日末では何れも同一の經過を 示すが，その後は各曲線多少の差翼を生じ $\mathrm{Cl}$ および $\mathrm{Br}$ の場合と同樣, 溫度 $100^{\circ}$, 濨宽 $100 \%$ の試料が抵抗が最 も大であり，溫度 $100^{\circ}$, 洆畜 $0 \%$ 特よび常溫のものは何 れもほとんど同一である。

\section{I $0.05 \%$ を含む試料}

Fig.4[B] に示寸如く，I 1\%の場合と同樣急激な抵抗 增加はなく，全期間にわたり比抵抗は徐々に增加する。こ の場合恪曲線とも差翼がほとんどない.なおI0.05\%を 含む方がI 1 \%を含むものより最初の抵抗值が大である.

\section{IV. 測定結果に對する者家}

$\mathrm{Cl}, \mathrm{Br}$ 扣よび I を含む $\mathrm{Se}$ の電氣抵抗の經年變化につ 
いて次の如く考える. すなわち $\mathrm{Cl}, \mathrm{Br}$ 抢よび I は $\mathrm{Se}$ 中 に入り，Se上り電子を 1 個取りそれぞれ $\mathrm{Cl}^{-}, \mathrm{Br}^{-}$拈よ び I- のイオンとして存在するものと考えられる. 從つて Se の外豰電子は 1 個不足となり, そこに正孔を生じ, こ の正孔が淔接の電氣傳導に寄與するものと考えられる. 故 に時間の經過に從つて, これら Cl, Br 拈よび I が Seか ら離挩する特は正孔の數子少くなり電氣抵抗は增加する. また含有量が $1 \%$ より $0.05 \%$ の方が抵抗が大であるの もこの考学加當然推察される.

次に常溫に怙忛る試料が一般に $100^{\circ}$ の場合よりも抵抗 增加が小なのは高溫程 $\mathrm{Cl}, \mathrm{Br}$ 扔よび I がガスとして試料 から離挩し易く, その結果正孔數の減少は $100^{\circ}$ の方が大 となり抵抗は大となる。

全般的に溫度怙よび濕度の影響は溫度が高く，かつ濕度 が大なる经ど抵抗徆加が甚しい，また溫度怙よび濕度を比 较すると溫度の方が抵抗增加に著しい影響を與える. 濕度 により抵抗が堧加するのは水分が作用して $\mathrm{SeO}_{2}$ あるいは $\mathrm{H}_{2} \mathrm{SeO}_{3}$ などを生ずるためと思われる.
なお $\mathrm{Cl}, \mathrm{Br}$ 招よび I のイオン化傾向からも知られる如 く，初期の抵抗は $\mathrm{Cl}, \mathrm{Br}$ 打よび I の順で, 約 $6 \times 10^{2} \Omega$ $\mathrm{cm}, 8 \times 10^{2} \Omega-\mathrm{cm}$ 打よび $1 \times 10^{3} \Omega-\mathrm{cm}$ の如く大になつて いる.

\section{V. 綿括}

以上を總括すると， $\mathrm{Cl}$ および $\mathrm{Br}$ を含む $\mathrm{Se}$ の電氣抵 抗は時間と子もに急激に增加し，大體數日にて一定の電氣 抵抗を示すようになるが，I を含さ Se は全期間にわたつ て徐々に抵抗の增加を示す．溫度括よび㬎度の影響は全般 的に高溫かつ多濕经ど抵抗增加の程度が大きい よつて整 流板の性能を考えたとき，電導度の點からいらと $\mathrm{Cl}$ を含 む場合が最も良く，I を含む場合が最も惡い，しかし經年 劣化の點から見ると，逆に急激な抵抗增加現象がないＩの 場合が最も安定で, $\mathrm{Cl}$ および $\mathrm{Br}$ の場合は不安定である.

終りに臨み各種の援助を與えられたる新電元工業株式會 社專務取締役深津五郎氏に對し深謝の意を表わすとつも に，實驗に協力された松前工學士に對し感謝する。 